$$
\begin{array}{ll}
\text { Volume } & : 04 \\
\text { Nomor } & : 03 \\
\text { Bulan } & : \text { September } \\
\text { Tahun } & : 2018 \\
\text { http } & : \text { /lejurnal.pps.ung.ac.id/index.php/AKSARA/index }
\end{array}
$$

\title{
Meningkatkan Prestasi Belajar Matematika Dengan Model Pembelajaran Problem-Based Learning Di SMK Negeri 1 Airmadidi
}

\author{
Deifi Greis Matindas \\ Guru SMK Negeri 1 Airmadidi \\ deifi@yahoo.com
}

\begin{abstract}
Abstrak
Dengan menggunakan model pembelajaran Problem-Based Learning prestasi belajar siswa Kelas XI TKJ-1 SMK Negeri 1 Airmadidi Tahun Pelajaran 2015/2016 pada materi pokok Logika menjadi lebih meningkat. Hal ini dapat dilihat dari perolehan nilai rata-rata ulangan harian yang semula sebelum diadakan penelitian 43,5 dengan ketuntasan $43 \%$. pada siklus $1=69,25$ dengan ketuntasan $69 \%$ dan pada siklus $2=74,0$ dengan ketuntasan $74 \%$.
\end{abstract}

Kata Kunci : Model pembelajaran Problem-Based Learning, motivasi, prestasi belajar matematika

\section{PENDAHULUAN}

Keberhasilan pembelajaran dalam arti tercapainya standar kompetensi, sangat bergantung pada kemampuan guru mengolah pembelajaran yang dapat menciptakan situasi yang memungkinkan siswa belajar sehingga merupakan titik awal berhasilnya pembelajaran (Semiawan, 1985). Banyaknya teori dan hasil penelitian para ahli pendidikan yang menunjukkan bahwa pembelajaran akan berhasil bila siswa berpartisipasi aktif dalam proses pembelajaran.

Pembelajaran Berbasis Masalah dikembangkan dari pemikiran nilai - nilai demokrasi, belajar efektif perilaku kerja sama dan menghargai keanekaragaman di masyarakat. Dalam pembelajaran guru harus dapat menciptakan lingkungan belajar sebagai suatu sistem sosial yang memiliki ciri proses demokrasi dan proses ilmiah. Pembelajaran berbasis masalah merupakan jawaban terhadap praktek pembelajaran kompetensi serta merespon perkembangan dinamika sosial masyarakat. Selain itu pembelajaran berbasis masalah pada dasarnya merupakan pengembangan lebih lanjut dari pembelajaran kelompok. Dengan demikian, metode pembelajaran berbasis masalah memiliki karakteristik yang khas yaitu menggunakan masalah dunia nyata sebagai konteks belajar bagi siswa untuk belajar tentang berpikir kritis dan keterampilan memecahkan masalah, serta untuk memperoleh pengetahuan dan konsep esensial dari materi pelajaran.

Pembelajaran berbasis masalah digunakan untuk merangsang berpikir tingkat tinggi dengan situasi berorientasi pada masalah, termasuk didalamnya belajar bagaimana belajar. Menurut Ibrahim dan Nur (2000:2 dalam Nurhadi dkk,2004), " Pembelajaran berbasis masalah dikenal dengan nama lain seperti Project-Based Learning (Pembelajaran Proyek), Eksperience-Based Education 


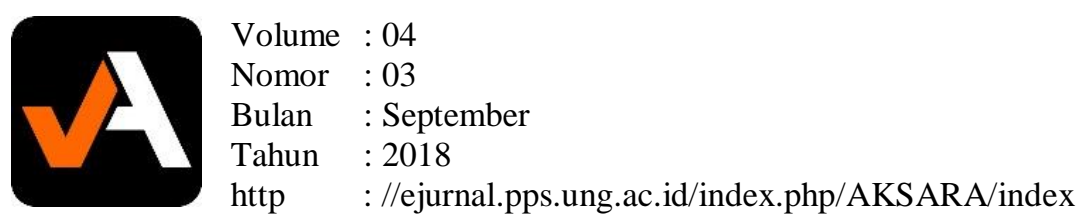

(Pendidikan Berdasarkan Pengalaman), Authentic learning (Pembelajaran Autentik), dan Anchored instruction (Pembelajaran berakar pada dunia nyata)". Peran guru dalam pembelajaran berbasis masalah adalah menyajikan masalah, mengajukan pertanyaan dan memfasilitasi penyelidikan dan dialog. Pembelajaran berbasis masalah tidak dapat dilaksanakan tanpa guru mengembangkan lingkungan kelas yang memungkinkan terjadinya pertukaran ide secara bebas. Prinsip pembelajaran berbasis masalah terdiri dari menyajikan kepada siswa situasi masalah yang autentik dan bermakna yang dapat memberikan kemudahan kepada mereka untuk melakukankan penyelidikan secara inkuiri.

\section{KAJIAN PUSTAKA}

Pembelajaran berbasis masalah digunakan untuk merangsang berpikir tingkat tinggi dalam situasi berorientasi masalah, termasuk didalamnya belajar bagaimana belajar. Menurut Ibrahim dan Nur (2002:2 dalam Nurhadi dkk, 2004), "Pembelajaran berbasis masalah dikenal dengan nama lain seperti Project-based Teaching (pembelajaran proyek), Experience-Based Education (pendidikan berdasarkan pengalaman), Authentic learning (Pembelajaran autentik), dan Anchored instructian (pembelajaran berakar pada kehidupan nyata)". Tahapan pembelajaran berbasis masalah

Pengajaran berbasis masalah biasanya terdiri dari lima tahapan utama yang dimulai guru memperkenalkan siswa dengan suatu situasi masalah yang diakhiri dengan penyajian dan analisa hasil kerja siswa.

a. Tahap pertama adalah orientasi siswa terhadap masalah. Guru menjelaskan tujuan pembelajaran, menjelaskan logistik yang dibutuhkan, memotivasi siswa agar terlibat dalam aktivitas pemecahan masalah yang dipilih.

b. Tahap kedua adalah mengorganisasi siswa untuk belajar. Guru membantu siswa mendefinisikan dan mengorganisasikan tugas belajar yang berhubungan dengan masalah tersebut.

c. Tahap ketiga adalah membimbing penyelidikan individual dan kelompok. Guru mendorong siswa untuk mengumpulkan informasi yang sesuai, melaksanakan eksperimen, untuk mendapatkan penjelasan dan penyelesaian masalahnya.

d. Tahap keempat adalah mengembangkan dan menyajikan hasil karya. Guru membantu siswa merencanakan dan menyiapkan karya yang sesuai dengan laporan, video dan model serta membantu mereka berbagi tugas dengan temannya.

e. Tahap kelima adalah menganalisis dan mengevaluasi proses pemecahan masalah. Guru membantu siswa melakukan refleksi atau evaluasi terhadap penyelidikan mereka dan proses-peoses yang mereka gunakan.

276 AKSARA Jurnal Ilmu Pendidikan Nonformal 


$\begin{array}{ll}\text { Volume } & : 04 \\ \text { Nomor } & : 03 \\ \text { Bulan } & : \text { September } \\ \text { Tahun } & : 2018 \\ \text { http } & : / / \text { ejurnal.pps.ung.ac.id/index.php/AKSARA/index }\end{array}$

\section{METODE PENELITIAN}

Penelitian dilaksanakan di SMK Negeri 1 Airmadidi pada kelas XI TKJ-1 sebagai kelas eksperimen dengan metode Problem Based Learning sedang kelas XI TKJ-2 sebagai kelas kontrol menggunakan metode ceramah pokok bahasan Logika.

SMK Negeri 1 Airmadidi yang beralamat di Jalan kantor Bupati Minahasa Utara, Kel. Airmadidi Atas Kecamatan Airmadidi. Jumlah siswa sebanyak 1040 siswa terdiri dari 39 kelas yang terbagi menjadi 3 tingkat yaitu tingkat X, XI dan XII dan 9 Jurusan sedangkan jumlah guru sebanyak 75 orang.

Sebagai obyek dalam penelitian ini adalah kelas XI TKJ-1 yang berjumlah 40 siswa dengan personalia :

Penelitian direncanakan menjadi dua siklus. Sedangkan waktunya mulai tanggal 23 Oktober s/d 6 November 2015. Langkah - langkah yang di tempuh dalam penelitian ini adalah :

1. Siklus I

a. Perencanaan ( Planning )

Dalam tahap Perencanaan Peneliti bersama Kolaborator mempersiapkan :

$>$ Silabus

$>$ Soal - soal ulangan harian

$>$ Instrumen penelitian

$>$ Materi dan rancangan pembelajaran yaitu Sistem Persamaan Linear Dua Variabel

b. Pelaksanaan ( Acting)

Tahap pelaksanaan dilaksanakan didalam kelas dengan melakukan kegiatan pembelajaran sesuai dengan rancangan pembelajaran yang telah direncanakan. Pengamatan ( Observing )

c. Refleksi ( Reflecting )

Dalam tahap ini bersama kolaborator melakukan kegiatan menganalisa, mensintesa dari hasil pengamatan selama proses pembelajaran pada siklus I berlangsung dan diadakan ulangan harian yang digunakan untuk mengetahui hasil belajar baik secara individu maupun klasikal dan membandingkan hasilnya dengan kelas X-2 (kelas kontrol) yang Peneliti lakukan pembelajarannya melalui metode ceramah menggunakan Teknik statistik Uji-T.Bila ternyata pada tahap ini seluruh siswa telah mencapai standar ketuntasan minimal, maka langsung dilanjutkan dengan siklus II.

2. Siklus II

Pada siklus II merupakan tindak lanjut dari siklus I dengan memperhatikan hasil observasi, dan hasil diskusi dengan Kolaborator serta 


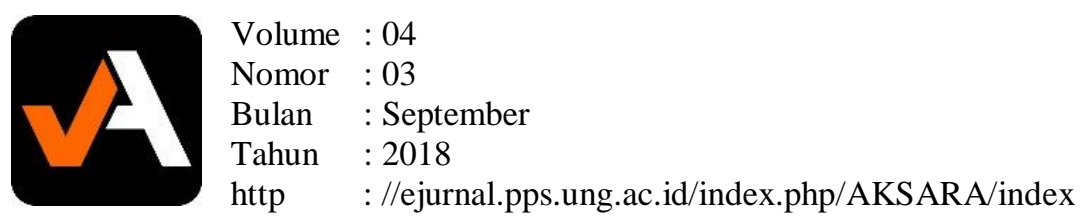

hasil belajar siswa dengan mengetahui ketuntasan belajar siswa secara individu maupun klasikal, maka Peneliti bersama Kolaborator merencanakan proses pembelajaran selanjutnya. Adapun langkah langkah pada siklus II adalah sebagai berikut:

a. Perencanaan

$>$ Menyiapkan silabus

$>$ Menyiapkan soal - soal evaluasi II

$>$ Instrumen penelitian

$>$ Materi dan rancangan pembelajaran yaitu Logika

b. Pelaksanan Tindakan

Siswa melaksanakan kegiatan belajar sesuai dengan rancangan pembelajaran yang telah ditentukan. Pada siklus II pelaksanaan pembelajaran perlu dimodifikasi dengan presentasi hasil kerja siswa dan kelompoknya dengan memanfaatkan Media Laptop dan LCD , ini diharapkan akan lebih memberi motivasi dan semangat siswa dalam belajar.

c. Pengamatan ( Observasi )

Ketika siswa melakukan kegiatan belajar pada siklus II, Kolaborator mengamati perubahan sikap dengan memberikan instrumen (angket) yang harus diisi oleh siswa dan juga diamati pembelajaran yang dilaksanakan.

d. Refleksi

Dalam tahap ini bersama kolaborator melakukan kegiatan menganalisa, mensintesa dari hasil pengamatan selama proses pembelajaran pada siklus II berlangsung, dan diadakan ulangan harian yang digunakan untuk mengetahui hasil belajar baik secara individual maupun klasikal dan membandingkan hasilnya dengan kelas XI TKJ-2 (kelas kontrol).

\section{HASIL PENELITIAN DAN PEMBAHASAN}

Tahapan penelitian tindakan ini berupa :

\section{A. Siklus 1}

1. Perencanaan

a. Guru melaksanakan kegiatan pembelajaran sesuai yang direncanakan dengan Kolaborator dengan bentuk klasikal.

b. Siswa duduk berkelompok sesuai dengan tempat duduk yang berdekatan dalam satu garis bangku dengan anggota $4-5$ orang.

c. Guru memberikan tugas secara berkelompok dan individu.

d. Guru mengamati proses berlangsungnya belajar kelompok.

e. Kolaborator membuat catatan pribadi (catatan lapangan).

f. Guru memberikan tes kepada siswa.

2. Pelaksanaan

278 AKSARA Jurnal Ilmu Pendidikan Nonformal 


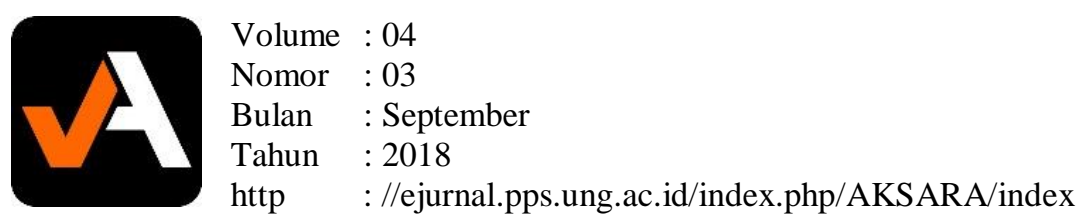

Siklus 1 ini merupakan tahap awal dari penelitian yaitu dengan mengambil data ulangan harian siswa yang terakhir sebelum diadakan penelitian, hal ini digunakan sebagai pembanding. Data ulangan harian yang terakhir kelas XI TKJ-1 sebagai kelas PTK dan kelas XI TKJ-2 sebagai kelas kontrol yang selanjutnya kita olah menggunakan komputer program SPSS versi 11 hasilnya adalah sebagai berikut :

Skor $\mathrm{T}_{\mathrm{h}}=-0,145$ dengan signifikansi $0,545(54,5 \%)$ dimana $\mathrm{T}_{\mathrm{t}}$ untuk $\mathrm{db}=78$ besarnya adalah 0,166 yang sehingga $\mathrm{T}_{\mathrm{h}}<\mathrm{T}_{\mathrm{t}}$ yang artinya kelompok eksperimen X-1 tidak berbeda reratanya dengan kelompok control X-2 pada saat Pra PTK. Hasil tersebut juga dapat dibaca dari signifikansi 54,5\% > 5\% yang memiliki arti tidak ada perbedaan rerata yang signifikan antara kelompok eksperimen X-1 dan kelompok kontrol X-2 saat pra PTK. Hasil lengkap analisa data out put SPSS Pra PTK dapat dicermati pada lampiran.

Pelaksanaan pembelajaran siklus 1 dilaksanakan pada tanggal 23 Oktober 2015 yang pelaksanaannya sebagai berikut :

Setelah tanda pelajaran dimulai Peneliti masuk ke kelas XI TKJ-1 yang dipilih untuk obyek penelitian. Peneliti mengucapkan salam kemudian dibahas tentang pernyataan dan kalimat terbuka. Peneliti memberikan pertanyaan-pertanyaan tentang pernyataan dan kalimat terbuka dengan tujuan untuk mengetahui sejauh mana pengetahuan siswa tentang pernyataan dan kalimat terbuka. Selain diharapkan dapat membangkitkan kreativitas siswa dalam mengungkapkan pendapat dan apa yang siswa ketahui tentang pernyataan dan kalimat terbuka. Kemudian siswa disuruh menyebutkan contoh-contoh pernyataan dan kalimat terbuka dalam kehidupan sehari-hari. Peneliti memberikan kesempatan kepada siswa untuk bertanya tentang apa yang belum difahami. Kemudian Peneliti menerangkan apa yang belum dimengerti oleh siswa sehingga siswa menjadi faham. Apabila siswa telah paham, maka Peneliti memberikan soal-soal untuk dikerjakan. Terlebih dahulu siswa disuruh membentuk kelompok secara heterogen yang beranggotakan $4-5$ orang dan soal tersebut dikerjakan secara berkelompok. Peneliti mengamati dan berkeliling untuk memberikan bimbingan bagi siswa yang masih mengalami kesulitan. Selanjutnya Peneliti menunjuk siswa untuk mengerjakan kedepan dari hasil pekerjaan yang telah dikerjakan. Sebelum kegiatan pembelajaran pertama berakhir, Peneliti memberikan soal-soal latihan (evaluasi 1) yang harus dikerjakan siswa dan selanjutnya dikumpulkan. Dari hasil latihan ini dijadikan sebagai sumber data pertama. ada kegiatan ini soal yang Peneliti berikan berjumlah 2 butir soal dengan nomor 1 (a sampai dengan e) dan nomor 2 (a sampai dengan e) dengan alokasi waktu 30 menit. 
$\begin{array}{ll}\text { Volume } & : 04 \\ \text { Nomor } & : 03 \\ \text { Bulan } & : \text { September } \\ \text { Tahun } & : 2018 \\ \text { http } & : / / \text { ejurnal.pps.ung.ac.id/index.php/AKSARA/index }\end{array}$

3. Pengamatan

Berdasarkan dari catatan lapangan, pada saat berlangsungnya belajar kelompok ada diantara salah satu kelompok yang dua anggotanya bercengkerama sendiri tentang hal diluar materi diskusi. Peneliti menegur dan menyuruh untuk aktif berinteraksi dengan kelompoknya dalam mendiskusikan masalah yang telah diberikan oleh Peneliti. Sementara itu ada seorang siswa yang makan makanan ringan didalam kelas kemudian ditegur oleh Peneliti. Pada setiap kelompok yang antusias membahas tugas yang diberikan rata-rata 2 atau 3 orang sedang anggota lain cukup aktif. Pengamatan diluar proses belajar kelompok yaitu Peneliti memeriksa buku catatan masing-masing siswa setelah penyajian materi. Ternyata ada beberapa siswa yang tidak mencatat dengan berbagai alasan

Hasil analisa data menggunakan komputer program SPSS versi 11 pada siklus 1 diperoleh hasil sebagai berikut :

Skor $T_{h}=2,584$ dengan signifikansi $0,006(0,6 \%)$ dimana $T_{t}$ untuk $d b=78$ besarnya adalah 0,166 yang sehingga $T_{h} \geq T_{t}$ yang artinya kelompok eksperimen X-1 berbeda reratanya dengan kelompok kontrol XI TKJ-2 setelah siklus 1. Hasil tersebut juga dapat dibaca dari signifikansi $0,6 \%<5 \%$ yang memiliki arti ada perbedaan rerata yang signifikan antara kelompok eksperimen XI TKJ-1 dan kelompok kontrol XI TKJ-2 saat setelah siklus 1. Hasil lengkap analisa data out put SPSS siklus 1 dapat dicermati pada lampiran.

\section{B. Pembahasan Hasil Penelitian}

Hasil analisa hasil keseluruhan siklus adalah sebagai berikut :

Tabel 10. Data Hasil Belajar PTK Kelas X-1

\begin{tabular}{|c|c|c|c|c|}
\hline No & Uraian & Pra PTK & Siklus 1 & Siklus 2 \\
\hline 1 & $\begin{array}{l}\text { Rata-rata nilai ulangan } \\
\text { harian }\end{array}$ & 43,5 & 69.25 & 74,0 \\
\hline
\end{tabular}

Tabel 11. Data Hasil Kenaikan Nilai Ulangan Secara Keseluruhan

\begin{tabular}{|c|l|c|c|c|c|}
\hline No & Uraian & $\begin{array}{c}\text { Pra } \\
\text { PTK }\end{array}$ & $\begin{array}{c}\text { Siklus } \\
1\end{array}$ & $\begin{array}{c}\text { Siklus } \\
2\end{array}$ & $\begin{array}{c}\text { Kenaikan } \\
\text { keberhasila } \\
\text { n }\end{array}$ \\
\hline 1 & $\begin{array}{l}\text { Rata-rata } \\
\text { kenaikan nilai } \\
\text { tiap siklus }\end{array}$ & 43,5 & 69,25 & 74,0 & 30,5 \\
\hline
\end{tabular}

Dari tabel diatas dapat dijelaskan bahwa penghitungan kenaikan keberhasilan secara keseluruhan diperoleh dari rata-rata setelah diadakan PTK atau siklus 2 dikurangi rata-rata sebelum diadakan PTK. Dengan 


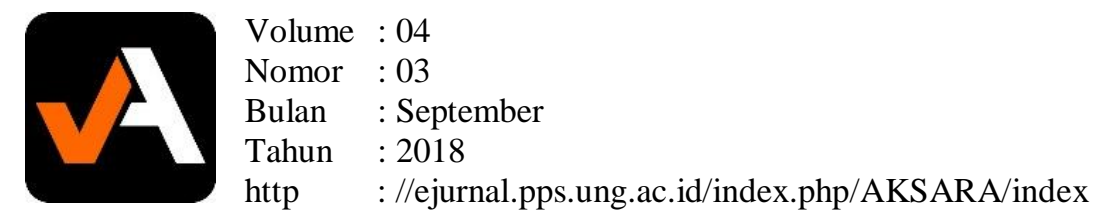

analisa $=74,0-43,5=30,5$. Hasil analisa dari distribusi frekuensi perolehan nilai dari keseluruhan siklus adalah sebagai berikut :

Tabel 12. Data Hasil Distribusi Frekuensi Perolehan Nilai dari Siklus1 ke Siklus 2

\begin{tabular}{|c|l|c|c|}
\hline No & Uraian & Siklus 1 & Siklus 2 \\
\hline 1 & Nilai $<90$ & 33 & 29 \\
2 & Nilai $\geq 90$ & 7 & 11 \\
\hline
\end{tabular}

Tabel 13. Data Hasil Kreatifitas Siswa Mencatat Materi Pelajaran Siklus 1 ke Siklus 2

\begin{tabular}{|c|l|c|c|}
\hline No & \multicolumn{1}{|c|}{$\begin{array}{c}\text { Keaktifan siswa } \\
\text { mencatat materi } \\
\text { pelajaran }\end{array}$} & $\begin{array}{c}\text { Siklus } \\
\text { I }\end{array}$ & Siklus II \\
\hline 1 & Aktif & 33 & 38 \\
2 & Cukup Aktif & 7 & 2 \\
\hline
\end{tabular}

Dari hasil analisa diperoleh:

1. Untuk keaktifan siswa dalam mencatat materi pelajaran antara siklus 1 ke siklus 2 mengalami kenaikan yaitu sebesar 15,15\%

2. Untuk siswa tidak aktif dalam mencatat materi pelajaran antara siklus 1 dan siklus 2 mengalami penurunan yaitu sebesar $-71,42 \%$

\section{Kesimpulan}

1. Terlihat pada saat belajar dan juga dari jawaban terhadap angket tentang metode pembelajaran Problem-Based Learning yang diisi siswa juga hasil observasi yang menunjukkan bahwa siswa lebih kreatif, aktif, bertanggung jawab dan mampu bekerja sama dalam kelompok.

2. Ada perbedaan prestasi belajar siswa yang diajar menggunakan metode Problem-Based Learning dengan metode ceramah pada pokok bahasan Logika kelas X-I SMK Negeri 1 Airmadidi Tahun Pelajaran 2015/2016. Hal ini terlihat dari hasil analisa statistik terhadap hasil pembelajaran menggunakan kedua metode dimana pada siklus $1 \mathrm{~T}_{h}=2,584$ dan $\mathrm{T}_{\mathrm{t}}=1,665$ pada $\mathrm{db}=78$ sedang pada siklus $2 \mathrm{~T}_{\mathrm{h}}=1,925$ dan $\mathrm{T}_{\mathrm{t}}=1,665$ pada $\mathrm{db}=78$ yang berarti $T_{h}>T_{t}$ sehingga hipotesa diterima.

\section{Saran}

Berdasarkan hasil penelitian tindakan kelas yang peneliti laksanakan dapat dikemukakan saran yang bermanfaat bagi peneliti selanjutnya ataupun guru sebagai berikut :

1. Pembelajaran matematika hendaknya bervariasi dan tidak monoton sehingga hasil pembelajaran dapat lebih maksimal. 


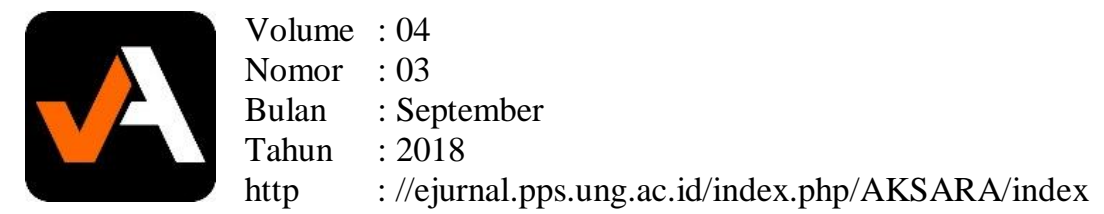

2. Agar kegiatan pembelajaran dapat berhasil dengan baik, maka seorang guru hendaknya selalu aktif dalam melibatkan siswa selama kegiatan pembelajaran berlangsung.

3. Seorang guru hendaknya trampil dan dapat menguasai berbagai metode pembelajaran agar siswa tidak bosan dan lebih mudah memahami materi pelajaran.

4. Terkait dengan penelitian ini hendaknya dikembangkan lagi instrumeninstrumen penelitian seperti angket dan lembar pengamatan kolaborator sehingga data yang kita peroleh dapat memberikan gambaran utuh tentang pelaksanaan pembelajaran yang kita laksanakan.

\section{Daftar Pustaka}

Arikunto, Suharsimi. 1982. Prosedur Penelitian Suatu Pendekatan Praktek. Jakarta: Bina Aksara

Dini R. 2005. Pengantar Dasar Matematika. Diktat Program Studi Matematika STKIP PGRI Blitar.

Djuweni. 2005. Penelitian Tindakan Kelas. Makalah disajikan dalam acara peningkatan Profesionalisme Guru, DIKDA Kota Blitar, SMP / SMA Kota Blitar, Maret 2005.

Dimyati, Mudjiono. 1998. Belajar Pembelajaran. Jakarta : Asdi Mahasatya.

Hadi, Sutrisno. 1986. Metodologi Research. Yogyakarta: Universitas Gajah Mada. Hudoyo, Herman. 1979. Pengembangan Kurikulum dan Pelaksanaannya di Depan Kelas. Surabaya: Usaha Nasional. 